\title{
EFFECT OF APPLICATION TIME AND RATES OF FOLIAR FERTILIZATION ON THE VEGETATIVE GROWTH, FLOWERING AND SOME MINERAL CONTENTS OF Brassica nigra L. Koch Abd El-Fattah, Y. M.M. \\ Horticulture Dept., Faculty of Agriculture, Suez Canal University, 41522
}

\begin{abstract}
This study was carried out during two successive seasons of 2005/2006 and $2006 / 2007$ to study the effect of application time and rate of foliar fertilization with complete fertilizer solution containing $20 \%, 20 \%, 20 \%$ of N, P and $\mathrm{K}$ at the rates of 2 , 4 and $6 \mathrm{~g} \mathrm{~L}^{-1}$ on vegetative growth, flowering and some chemical constituents of Brassica nigra [L.] Koch. All foliar fertilization treatments exhibited remarkable significant effects on plant height, number of branches, number of leaves, number of inflorescences, herbage fresh and dry weights, inflorescence fresh and dry weights and seed yield dry weight when compared with untreated plants.

Chemical analysis showed that the highest content of N, P, K were obtained, in general, from plants sprayed with $4 \mathrm{~g} \mathrm{~L}^{-1}$ of the complete fertilizer solution sprayed either every 10 or 20 days.

Concerning the micronutrient contents ( $\mathrm{Fe}, \mathrm{Mn}$, and $\mathrm{Zn}$ ) in leaves of $B$. nigra [L.] Koch, foliar fertilization resulted in significant effect on $\mathrm{Fe}, \mathrm{Mn}$ and $\mathrm{Zn}$ in leaves when compared with untreated plants. The highest content of chlorophyll $a$ and $b$ in leaves was found in plants sprayed with complete fertilizer solution at the rate of $4 \mathrm{~g} \mathrm{~L}$ 1.

Generally, the maximum increase in the studied parameters resulted from spraying plants with $4 \mathrm{~g} \mathrm{~L}^{-1}$ of complete fertilizer every either 10 or 20 days. So, economically the results recommend spraying mustard plants with $4 \mathrm{~g} \mathrm{~L}^{-1}$ complete fertilizer 20-20-20 every 20 days.

Keywords: Brassica nigra [L.] Koch - foliar fertilization -N P K fertilization - Mustard.
\end{abstract}

\section{INTRODUCTION}

Brassica nigra (black mustard) is an annual plant cultivated for its seeds, which are commonly used as a spice. The plant is believed to be native to the southern Mediterranean region of Europe, and has been cultivated for thousands of years. The spice is generally made from ground seeds of the plant, with the seed coats removed. The small $(1 \mathrm{~mm})$ seeds are hard and vary in color from dark brown to black. They are flavorful, although they have almost no aroma. The seeds are commonly used in Indian cuisine, for example in curry. The seeds have a significant amount of fatty oil. This oil is used often as cocking oil in India (Anonymous, 2009).

Brassica nigra [L.] Koch "black mustard" is a member of Brassiceae family. It is an annual herbaceous plant, widely cultivated in China and India. Mustard is a cool weather crop and grows up to 3 meter. It likes a moist and a sunny location. Seed pods harvested in late summer before they become dry, and allow the seeds to ripen in the pods at shade (Brickell and Zuk, 1996). 
Black mustard is a common spice used in the entire world. All parts of the mustard plant are edible, including leaves, flowers and seeds. Mustard works well with all types of meats, poultry and seafood. Seeds and leaves used as salad greens (James, 2002).

Nowadays, soil alkalinity and pollution are considered as the most important problems in Benghazi Libya. Moreover, using of mineral fertilizers in agriculture production have resulted in serious problem in the soil and contaminate the underground water.

Foliar fertilization is frequently applied in horticultural practice. This fertilization is recommended in an integrated plant production because it is environmental friendly and gives the possibility to achieve high productivity and good quality yields. This application is successful for all crops, since soil surface application of most fertilizers has little effect on rapid improvement of plant nutrition (Weinbaum et al., 2002). Foliar fertilization should be applied under conditions of decreased nutrient availability in soil $(\mathrm{pH})$, dry topsoil, and decreased root activity (Wójcik 2004).

\section{MATERIALS AND METHODS}

This study was conducted during two successive seasons of 2005/2006 and 2006/2007 at the Experimental Farm, Faculty of Agriculture, University of Benghazi Libya. The soil of the experimental field was clay in texture, the physical and chemical analysis of the soil are shown in Table 1.

Table (1): physical and chemical properties of the experimental soil

\begin{tabular}{|l|l|c|c|}
\hline \multirow{2}{*}{} & \multirow{2}{*}{ Characters } & \multicolumn{2}{|c|}{ Value } \\
\cline { 2 - 4 } & & Season 2005 & Season 2006 \\
\hline \multirow{4}{*}{ Physical properties } & Sand \% & 18.57 & 18.42 \\
\cline { 2 - 4 } & Silt \% & 39.36 & 32.50 \\
\cline { 2 - 4 } & Clay \% & 42.07 & 49.07 \\
\cline { 2 - 4 } & Texture grade & Clay & Clay \\
\hline \multirow{5}{*}{ Chemical properties } & $\mathrm{pH}$ & 8.30 & 8.40 \\
\cline { 2 - 4 } & Ec (dsm ${ }^{-1}$ at 25 $\left.{ }^{\circ} \mathrm{C}\right)$ & 0.66 & 0.71 \\
\cline { 2 - 4 } & Total soluble N(ppm) & 15.2 & 16.00 \\
\cline { 2 - 4 } & Available P $(\mathrm{ppm})$ & 37.5 & 39.10 \\
\cline { 2 - 4 } & Available K $(\mathrm{ppm})$ & 37.5 & 3.00 \\
\hline
\end{tabular}

Seeds of Brassica nigra [L.] Koch were obtained from Ministry of Agriculture, Egypt and sown at $50 \times 50 \mathrm{~cm}$ apart in plots on $16^{\text {th }}$ and $20^{\text {th }}$ of November in both seasons, respectively. Treatments were arranged in a complete randomized block design (CRBD) with four replicates, each replicate contained 20 plants.

A formula of nitrogen, phosphorus and potassium was prepared from ammonium sulphate, urea, potassium nitrate, potassium dihydrogen phosphate and potassium sulphate. Calcium and magnesium of the Glenhazel basic formula no. 2 as 180 and 50 ppm from calcium sulphate and magnesium sulphate, respectively, were used for all the treatments. Besides trace basic elements solution $A$ at the rates of $4.0,0.5,0.5,0.5$ and $0.05 \mathrm{ppm}$ from $\mathrm{Fe}, \mathrm{B}, \mathrm{Mn}, \mathrm{Zn}$ and $\mathrm{Cu}$ were used from ferrous sulphate, boric acid, 
manganese sulphate, zinc sulphate and copper sulphate, respectively (Bentley, 1982). The final formula was $20 \% \mathrm{~N}: 20 \% \mathrm{P}_{2} \mathrm{O}_{5}: 20 \% \mathrm{~K}_{2} \mathrm{O}$. Plants were sprayed with aqueous solution of $2 \%, 4 \%$ and $6 \%$ for every plant until the solution was run-off every either 10 or 20 days beginning from $20^{\text {th }}$ of December during both seasons.

\section{The experiments included 7 treatments:}

1 - control plants which sprayed with water

2- plants sprayed three times with $2 \%$ aqueous solution of fertilizers every 10 days

3- plants sprayed three times with $4 \%$ aqueous solution of fertilizers every 10 days

4- plants sprayed three times with $6 \%$ aqueous solution of fertilizers every 10 days

5- plants sprayed three times with $2 \%$ aqueous solution of fertilizers every 20 days

6- plants sprayed three times with $4 \%$ aqueous solution of fertilizers every 20 days

7- plants sprayed three times with $6 \%$ aqueous solution of fertilizers every 20 days

All normal cultural practices were done. Data for vegetative growth and chemical analyses were recorded at the end of both seasons in $15^{\text {th }}$ April. The treatments were repeated in both seasons. Data were recorded for the following parameters:

1- Growth parameters:

- Plant height (cms).

- Number of branches / plant

- Number of leaves / plant

- Number of inflorescence / plant

- Herbage fresh weight / plant $(\mathrm{g})$

- Herbage dry weight / plant (g).

- Inflorescence fresh weight / plant (g).

- Inflorescence dry weight / plant (g).

- Seed yield dry weight / plant (g).

\section{2- Chemical analysis:}

- Plant Nitrogen, phosphorus, potassium, Mg, Fe and Zn content were determined according to the methods described by Sadasivam and Manickan (1991).

- Leaf Chlorophyll $a$ and $b$ content were determined according to Sadasivam and Manickan (1991).

Data were statistically analyzed

All data were subjected to the statistical analysis using ANOVA, Tukey's test with the SPSS program and the means were separated according to the methods mentioned by Gomez and Gomez (1984).

\section{Results and Discussion}

\section{1- Vegetative growth}

Generally, results presented in Table 2 show that the effect of spraying Brassica nigra (black mustard) plants with any concentration at any 
interval of application showed significant increase of the studied vegetative characters.

It is obvious from Table (2) that spraying black mustard plants with aqueous solution of $4 \mathrm{~g} \mathrm{~L}^{-1}$ three times every 10 days significantly increased plant height as compared to other treatments.

The results presented in Table (2) clearly show that spraying plants with aqueous solution containing $2 \mathrm{~g} \mathrm{~L}^{-1}$ three times every 20 days significantly increased number of branches and leaves per plant compared to other application treatments in the first and second seasons. However, spraying plants with aqueous solution containing $6 \mathrm{~g} \mathrm{~L}^{-1}$ three times every 10 days significantly increased number of inflorescences produced by plant.

Generally, similar increases in vegetative or flowering characters as a result of foliar fertilization treatments have been reported by Kolota and Osinska (2001) on cabbage and cucumber, Shaaban et al. (2004) on tomato plants and Salem and Awad (2005) on Coriandrum sativium L.

Agina et al. (2005) on some ornamental plants and El-Sallami and Gad (2005) on Aster novi belgiil found that foliar fertilization increased number of branches and leaves/plant.

Table (2) effect of foliar nutrition and time of application on vegetative growth of Brassica nigra during 2005 and 2006 seasons

\begin{tabular}{|c|c|c|c|c|c|c|c|c|}
\hline \multirow[t]{3}{*}{ Treatment } & \multicolumn{2}{|c|}{\begin{tabular}{|c|}
$\begin{array}{c}\text { plant height } \\
(\mathrm{cm})\end{array}$ \\
\end{tabular}} & \multicolumn{2}{|c|}{$\begin{array}{l}\text { Number of } \\
\text { branches }\end{array}$} & \multicolumn{2}{|c|}{$\begin{array}{l}\text { Number of } \\
\text { leaves/plant }\end{array}$} & \multicolumn{2}{|c|}{$\begin{array}{c}\text { No. of } \\
\text { florescence/plant }\end{array}$} \\
\hline & \multicolumn{8}{|c|}{ Seasons } \\
\hline & $1^{\text {st }}$ & $2^{\text {nd }}$ & $1^{\text {st }}$ & $2^{\text {nd }}$ & $1^{\text {st }}$ & $2^{\text {nd }}$ & $1^{\mathrm{st}}$ & $2^{\text {nd }}$ \\
\hline Control & $189 \mathrm{c}$ & $205 \mathrm{c}$ & $8.00 \mathrm{c}$ & $8.50 \mathrm{c}$ & $74.0 \mathrm{~d}$ & $77.33 \mathrm{~d}$ & $13.00 \mathrm{c}$ & $15.33 c$ \\
\hline $2 \mathrm{~g} / \mathrm{L} / 10$ days & $275 a$ & $285 \mathrm{a}$ & $12.50 \mathrm{~b}$ & $11.20 \mathrm{~b}$ & $18.66 \mathrm{bc}$ & $125.0 \mathrm{c}$ & $36.66 \mathrm{~b}$ & $42.33 \mathrm{~b}$ \\
\hline $4 \mathrm{~g} / \mathrm{L} / 10$ days & $284 \mathrm{a}$ & $305 a$ & $15.25 \mathrm{a}$ & $16.85 \mathrm{a}$ & $126.00 \mathrm{bc}$ & $135.33 \mathrm{~b}$ & $45.66 \mathrm{a}$ & $49.33 \mathrm{~b}$ \\
\hline $6 \mathrm{~g} / \mathrm{L} / 10$ days & $259 \mathrm{~b}$ & $255 \mathrm{~b}$ & $15.25 \mathrm{a}$ & $15.45 \mathrm{a}$ & $116.10 \mathrm{bc}$ & $122.66 \mathrm{bc}$ & $75.00 \mathrm{a}$ & $83.66 \mathrm{a}$ \\
\hline $2 \mathrm{~g} / \mathrm{L} / 20$ days & $245 \mathrm{~b}$ & $230 \mathrm{~b}$ & $17.00 \mathrm{a}$ & $17.35 \mathrm{a}$ & $175.33 \mathrm{a}$ & $181.66 \mathrm{a}$ & $50.66 \mathrm{~b}$ & $60.00 \mathrm{ab}$ \\
\hline $4 \mathrm{~g} / \mathrm{L} / 20$ days & $265 a b$ & $240 \mathrm{~b}$ & $15.00 \mathrm{a}$ & $15.25 \mathrm{a}$ & $148.33 \mathrm{~b}$ & $170.00 \mathrm{a}$ & $59.66 \mathrm{~b}$ & $63.33 \mathrm{ab}$ \\
\hline $6 \mathrm{~g} / \mathrm{L} / 20$ days & $254 \mathrm{~b}$ & $230 \mathrm{~b}$ & $13.50 \mathrm{a}$ & $13.40 \mathrm{a}$ & $166.33 \mathrm{ab}$ & $153.33 \mathrm{~b}$ & $54.00 \mathrm{~b}$ & $57.66 \mathrm{~b}$ \\
\hline
\end{tabular}

From data in Table (3), it was noticed that spraying plants with $2 \mathrm{~g} \mathrm{~L}^{-1}$ three times every 20 days had a pronounced effects on herb fresh and dry weights of Brassica nigra plants during both seasons. Meanwhile, plants subjected to spraying with the medium concentration of $4 \mathrm{~g} \mathrm{~L}^{-1}$ for three times at the intervals of 20 days produced the heaviest fresh and dry weights of inflorescences during the first and second seasons. Besides, production of dry seeds per plant by this treatment was higher.

On the other hand, control plants which sprayed with water resulted in the lowest values for herb fresh and dry weights, fresh and dry weights of inflorescences per plant as well as dry seeds produced from every plant.

The increase in vegetative growth as affected by the application of fertilizers may be due to that nitrogen led to synthesis or formation of amino acids which considered a basics for protein formation, which participates in cell enlargement and cell division (Taiz and Zeiger 2008). The previous results are in conformity with those of El-Gendy et al., (2001) on Ocimum basilicum and Moghazy and Abd El-Fattah (2005) on Hibiscus sabdiffera L. 
Trejo-Téllez et al., (2007) concluded that foliar fertilizers containing $\mathrm{N}, \mathrm{P}, \mathrm{K}$ and micronutrients are commonly recommended as the most efficient method of increasing yield and improve quality of crop products.

Table (3) Effect of time application and foliar nutrition on herbage and inflorescence of Brassica nigra during 2005 and 2006 seasons

\begin{tabular}{|c|c|c|c|c|c|c|c|c|c|c|}
\hline \multirow[t]{3}{*}{ Treatment } & \multicolumn{2}{|c|}{$\begin{array}{l}\text { Herb fresh } \\
\text { weight }(g)\end{array}$} & \multicolumn{2}{|c|}{$\begin{array}{l}\text { Herb dry } \\
\text { weight (g) }\end{array}$} & \multicolumn{2}{|c|}{$\begin{array}{l}\text { Inflorescence } \\
\text { fresh weight }\end{array}$} & \multicolumn{2}{|c|}{$\begin{array}{l}\text { Inflorescence } \\
\text { dry weight }\end{array}$} & \multicolumn{2}{|c|}{$\begin{array}{l}\text { seed yield } \\
\text { dry weight } \\
\text { /plant }\end{array}$} \\
\hline & \multicolumn{10}{|c|}{ Seasons } \\
\hline & $1^{\text {st }}$ & & $1^{\text {st }}$ & & $1^{\text {st }}$ & $2^{\text {nd }}$ & $1^{\text {st }}$ & & $1^{\text {st }}$ & $2^{\text {nd }}$ \\
\hline Con & 2328 & $21.10 \mathrm{~d}$ & $81.32 \mathrm{~d}$ & $.80 \mathrm{c}$ & $9.80 \mathrm{c}$ & 191 & 230 & $0.90 \mathrm{c}$ & $0.15 \mathrm{c}$ & 1.44 \\
\hline & & & 158 & & & & & & & 4.58 \\
\hline & & & 199 & & & & & & & 7.58 \\
\hline & 621 & & $97.61 \mathrm{bc}$ & & & & & & & 22.70 \\
\hline $2 g / L$ & 725 & $8 \mathrm{a}$ & $138.70 \mathrm{a}$ & 14 & $75 \mathrm{~b}$ & $\mathrm{~b}$ & $6 a b$ & & $37 \mathrm{a}$ & 19.15 \\
\hline $4 g / L$ & 700. & $5 \mathrm{ab}$ & $129.06 \mathrm{ab}$ & $139.90 \mathrm{a}$ & $302.87 \mathrm{a}$ & & & & $24.42 \mathrm{a}$ & $28.15 \mathrm{a}$ \\
\hline $6 \mathrm{~g} / \mathrm{L} / 20$ days & $633.61 \mathrm{c}$ & $641.86 \mathrm{c}$ & $92.20 \mathrm{c}$ & $99.30 \mathrm{~b}$ & $179.55 \mathrm{~b}$ & $184.88 \mathrm{~b}$ & $50.25 \mathrm{bc}$ & $49.25 \mathrm{~b}$ & $15.62 \mathrm{a}$ & 18.10 \\
\hline
\end{tabular}

\section{2- Mineral contents of leaves}

Nitrogen and potassium percentages of Brassica nigra leaves significantly increased with foliar nutrition rates, compared with those of the control in both growing season (Table 4). The highest value of leaves $\mathrm{N}, \mathrm{P}$ and $\mathrm{K}$ were obtained from the application of $4 \mathrm{~g} \mathrm{~L}^{-1}$ three times every 10 days and $4 \mathrm{~g} \mathrm{~L}^{-1}$ three times every 20 days. The difference between these two application rates was not significant. Meanwhile, the leaves content of N, P and $\mathrm{K}$ were increased by increasing concentrations of foliar application up to $4 \mathrm{~g} \mathrm{~L}^{-1}$. Data presented in (Table 5) reveal that micronutrients (Fe, $\mathrm{Mn}$ and $\mathrm{Zn}$ ) content of the leaves of Brassica were significant with the different concentrations of fertilization treatment compared to control during both season.

Table (4) Macronutrients and Micronutrients concentration in leaves of Brassica nigra as affected by foliar nutrition during the winter seasons of 2005/2006 and 2006/2007 under clay soils condition

\begin{tabular}{|c|c|c|c|c|c|c|}
\hline \multirow{3}{*}{ Treatment } & \multicolumn{2}{|c|}{$\mathbf{N} \%$} & \multicolumn{2}{|c|}{$\mathbf{P} \%$} & \multicolumn{2}{|c|}{ K \% } \\
\hline & \multicolumn{6}{|c|}{ Seasons } \\
\hline & $1^{\text {st }}$ & $2^{\text {nd }}$ & $1^{\text {st }}$ & $2^{\text {nd }}$ & $1^{\text {st }}$ & $2^{\text {nd }}$ \\
\hline Control & $2.01 \mathrm{c}$ & $2.11 \mathrm{c}$ & $0.40 \mathrm{c}$ & $0.49 \mathrm{c}$ & $0.81 \mathrm{c}$ & $0.89 \mathrm{c}$ \\
\hline $2 \mathrm{~g} / \mathrm{L} / 10$ days & $2.40 \mathrm{~b}$ & $2.49 \mathrm{~b}$ & $0.57 \mathrm{~b}$ & $0.67 \mathrm{~b}$ & $1.15 \mathrm{~b}$ & $1.06 \mathrm{c}$ \\
\hline $4 \mathrm{~g} / \mathrm{L} / 10$ days & $3.15 \mathrm{a}$ & $3.00 \mathrm{a}$ & $0.77 \mathrm{a}$ & $0.61 \mathrm{~b}$ & $1.28 \mathrm{a}$ & $1.41 \mathrm{a}$ \\
\hline $6 \mathrm{~g} / \mathrm{L} / 10$ days & $2.55 \mathrm{~b}$ & $2.70 \mathrm{~b}$ & $0.62 \mathrm{~b}$ & $0.70 \mathrm{~b}$ & $1.07 \mathrm{~b}$ & $1.16 \mathrm{~b}$ \\
\hline $2 \mathrm{~g} / \mathrm{L} / 20$ days & $2.50 \mathrm{~b}$ & $2.68 \mathrm{~b}$ & $0.70 \mathrm{~b}$ & $0.85 \mathrm{a}$ & $1.25 \mathrm{a}$ & $1.12 \mathrm{~b}$ \\
\hline $4 \mathrm{~g} / \mathrm{L} / 20$ days & $3.15 \mathrm{a}$ & $3.37 \mathrm{a}$ & $0.83 \mathrm{a}$ & $0.96 \mathrm{a}$ & $1.33 \mathrm{a}$ & $1.44 \mathrm{a}$ \\
\hline $6 \mathrm{~g} / \mathrm{L} / 20$ days & $2.47 \mathrm{~b}$ & $2.55 \mathrm{~b}$ & $0.69 \mathrm{~b}$ & $0.77 b$ & $1.28 \mathrm{a}$ & $1.19 \mathrm{~b}$ \\
\hline
\end{tabular}

The most favorable concentration of $\mathrm{Fe}, \mathrm{Mn}$ and $\mathrm{Zn}$ spraying in this respect were obtained by $6 \mathrm{~g} \mathrm{~L}^{-1}$ three times every 20 days in the first season, but in the second season it was respect was $4 \mathrm{~g} \mathrm{~L}^{-1}$ three times every 10 days. Foliar application is particularly useful under conditions when nutrient uptake from the soil is unavailable. This is often the case for the micronutrients such 
as $\mathrm{Fe}, \mathrm{Zn}$ and $\mathrm{Mn}$. These nutrients are frequently retained or fixed by soil particles and for this reason are scarcely available to plant roots. Foliar application in the form of either inorganic salts or chelates is a valuable tool in combating nutrient deficiencies. As micronutrients are only required in small quantities, foliar spray applied once or twice and correctly timed, is adequate to meet the demand of the crop.

Results of Kolota and Osinska (2001) showed that the optimum foliar fertilization in concentrations of $1.5 \%$ and $3.0 \%$ four times during the intensive period of plant growth at two week intervals increased the marketable yield in cabbage and cucumber.

Fritz (1978) added that repeated application of small units of foliar fertilizers are stimulating plant metabolism and increased nutrient uptake. Total production as well as its quality is improved by foliar fertilization. The stimulating effect of foliar fertilization depends on sound basic fertilizer rates including the supply of trace elements either via root or via the foliage.

Shaaban et al. (2004) found that when tomato plants received NPK as foliar fertilization, concentrations of $\mathrm{K}, \mathrm{Ca}$ and $\mathrm{Mg}$ in leaves as well as in the fruits were increased.

Bowman and Paul (1992) showed comparable $\mathrm{N}$ absorption rates by Lolium leaves as a result of foliar applications of urea, ammonium and nitrate. On the other hand, Wojcik (2004) reviewed that a higher absorption rate of $\mathrm{N}$ by the leaves treated with urea that those treated with nitrate or ammonium. Also Furuya and Umemiya (2002) reported that peach (Prunus persica Batsch) leaf treatment with urea appeared to be more effective in increasing $\mathrm{N}$ content than other inorganic forms of $\mathrm{N}$. Studies of Reickenberg and Pritts (1996) concluded that absorption of urea by the leaves of most crops is greater and faster than that of inorganic $\mathrm{N}$ forms. This phenomenon is related to the fact that the cuticular membrane is 10 to 20 times more permeable to urea than to inorganic ions (Kolattukudy, 1996). It is believed that urea molecules facilitate the penetration of other leaf applied nutrients (Weinbaum, 1988). Therefore, many foliar fertilizers contain some addition of urea to improve the efficiency of absorption of mineral nutrients. Wójcik, (2004) showed that the rates of $\mathrm{P}$ uptake was higher with $\mathrm{K}_{2} \mathrm{HPO}_{4}$ than any source.

Knoche et al. (1994) states that there is a strong correlation between nutrient concentration on a leaf surface and the rate of its uptake by the epidermal cells. However, elevated nutrient concentrations may cause some leaf troubles leading to the reduction in nutrient absorption. According to Marschner (1995) such absorption by these leaves is limited by the destruction of ectodesmata structures. Maximum concentrations of particular mineral nutrients in a spray solution depend on plant species, plant development stage, nutritional plant status, plant healthiness, and weather conditions.

Addition of foliar fertilizers containing $\mathrm{N}, \mathrm{P}$ and $\mathrm{K}$ to different medicinal and aromatic plants has become popular in recent years for their favorable effect on growth and flowering. Altland et al (2002) reported that supplying vinca, marigold and salvia plants with Osmocote NPK 14:14:14 or 17:17:12 produced the best in large and more attractive plants. 
Foliar application is particularly useful under some conditions where nutrients uptake from the soil is restricted. This is often the case for the micronutrients such as $\mathrm{Fe}, \mathrm{Zn}, \mathrm{Mn}$ and $\mathrm{Cu}$ which plays a very important role in vital processes of plants (Mortvedt et al., 1991).

Foliar application of micronutrients proved to be effective on vegetative growth parameters and flower yield of Tagetes patula (Omer. 1992), Zinnia elegans (Manoly, 2001), and Pelargonium hortorum (Frost et al., 2003), and Coriandrum sativum (Salem and Awad, 2005).

The objective of this study was to investigate the effect of foliar fertilization with a complete fertilizer containing $\mathrm{N}, \mathrm{P}$ and $\mathrm{K}$ at a formula of 20 : 20; 20 at a rates of 2 or 4 or $6 \mathrm{~g} \mathrm{~L}^{-1}$ every 10 or 20 days on the vegetative characters and yield of Brassica nigra [L.] Koch.

Table (5) Effect of treatments on Fe, Mn and Zin (ppm) in leaves of Brassica nigra during the two seasons of 2005 and 2006

\begin{tabular}{|c|c|c|c|c|c|c|}
\hline \multirow[t]{3}{*}{ Treatment } & \multicolumn{2}{|c|}{$\mathrm{Fe}$} & \multicolumn{2}{|c|}{ Mn } & \multicolumn{2}{|c|}{ Zin (ppm) } \\
\hline & & & sea & & & \\
\hline & $1^{\text {st }}$ & $2^{\text {nd }}$ & $1^{\text {st }}$ & $2^{\text {nd }}$ & $1^{\text {st }}$ & $2^{\text {nd }}$ \\
\hline Control & $0.150 \mathrm{c}$ & $0.161 \mathrm{~b}$ & $0.148 \mathrm{c}$ & $0.155 \mathrm{c}$ & $25.80 \mathrm{c}$ & $30.14 \mathrm{c}$ \\
\hline $2 \mathrm{~g} / \mathrm{L} / 10$ days & $0.174 \mathrm{~b}$ & $0.192 \mathrm{a}$ & $0.173 \mathrm{~b}$ & $0.191 \mathrm{~b}$ & $41.35 \mathrm{~b}$ & $38.28 \mathrm{c}$ \\
\hline $4 \mathrm{~g} / \mathrm{L} / 10$ days & $0.199 a$ & $0.211 \mathrm{a}$ & $0.96 \mathrm{a}$ & $0.230 \mathrm{a}$ & $54.10 \mathrm{a}$ & $61.20 \mathrm{a}$ \\
\hline $6 \mathrm{~g} / \mathrm{L} / 10$ days & $0.169 \mathrm{~b}$ & $0.182 \mathrm{a}$ & $0.195 \mathrm{a}$ & $0.184 \mathrm{~b}$ & $44.95 \mathrm{~b}$ & $46.95 \mathrm{~b}$ \\
\hline $2 \mathrm{~g} / \mathrm{L} / 20$ days & $0.180 \mathrm{ab}$ & $0.185 \mathrm{a}$ & $0.177 \mathrm{~b}$ & $0.192 \mathrm{~b}$ & $57.25 \mathrm{a}$ & $61.25 \mathrm{a}$ \\
\hline $4 \mathrm{~g} / \mathrm{L} / 20$ days & $0.208 \mathrm{a}$ & $0.227 \mathrm{a}$ & $0.229 a$ & $0.201 \mathrm{~b}$ & $66.17 \mathrm{a}$ & $66.04 \mathrm{a}$ \\
\hline $6 \mathrm{~g} / \mathrm{L} / 20$ days & $0.177 \mathrm{~b}$ & $0.186 \mathrm{a}$ & $0.182 \mathrm{a}$ & $0.191 \mathrm{~b}$ & $47.63 \mathrm{~b}$ & $50.15 a$ \\
\hline
\end{tabular}

Table (6) Effect of treatments on Chlorophyll content $(\mathrm{mg} / \mathrm{g}$ fresh weight) in leaves of Brassica nigra during the two seasons of 2005 and 2006

\begin{tabular}{|l|c|c|c|c|}
\hline Treatment & \multicolumn{2}{|c|}{$\begin{array}{c}\text { Chlorophyll a (mg/g fresh } \\
\text { weight) }\end{array}$} & \multicolumn{2}{c|}{$\begin{array}{c}\text { Chlorophyll b } \\
\text { (mg/g fresh weight) }\end{array}$} \\
\hline & $\mathbf{1}^{\text {st }}$ season & $\mathbf{2}^{\text {nd }}$ season & $\mathbf{1}^{\text {st }}$ season & $\mathbf{2}^{\text {nd }}$ season \\
\hline Control & $0.44 \mathrm{c}$ & $0.59 \mathrm{c}$ & $0.55 \mathrm{c}$ & $0.77 \mathrm{~V}$ \\
\hline $2 \mathrm{~g} / \mathrm{L} / 10$ days & $0.84 \mathrm{~b}$ & $0.98 \mathrm{~b}$ & $0.75 \mathrm{~b}$ & $0.97 \mathrm{~b}$ \\
\hline $4 \mathrm{~g} / \mathrm{L} / 10$ days & $1.18 \mathrm{a}$ & $1.43 \mathrm{a}$ & $1.02 \mathrm{a}$ & $1.26 \mathrm{a}$ \\
\hline $6 \mathrm{~g} / \mathrm{L} / 10$ days & $0.94 \mathrm{a}$ & $1.10 \mathrm{~b}$ & $0.85 \mathrm{~b}$ & $0.99 \mathrm{~b}$ \\
\hline $2 \mathrm{~g} / \mathrm{L} / 20$ days & $0.81 \mathrm{~b}$ & $0.93 \mathrm{~b}$ & $0.74 \mathrm{~b}$ & $1.02 \mathrm{~b}$ \\
\hline $4 \mathrm{~g} / \mathrm{L} / 20$ days & $0.99 \mathrm{a}$ & $1.29 \mathrm{a}$ & $0.93 \mathrm{a}$ & $1.37 \mathrm{a}$ \\
\hline $6 \mathrm{~g} / \mathrm{L} / 20$ days & $0.81 \mathrm{~b}$ & $1.05 \mathrm{~b}$ & $0.8 \mathrm{~b}$ & $1.11 \mathrm{~b}$ \\
\hline
\end{tabular}

Wójcik, (2004) also showed that foliar application of nutrient solutions causes salt concentrations on a leaf surface to be higher than those of soil solutions. Increased tolerance of the epidermis to high spray solution concentrations is caused by the presence of the wax layer and the cuticular membrane. Since most mineral nutrients passively diffuse into the epidermal cells, absorption deends on their concentrations on the leaf surface. Knoche et al. (1994) states that there is a strong correlation between nutrient concentration on a leaf surface and the rate of its uptake by the epidermal cells. However, elevated nutrient concentrations may cause some leaf troubles leading to the reduction in nutrient absorption. According to Marschner (1995) such absorption by these leaves is limited by the 
destruction of ectodesmata structures. Maximum concentrations of particular mineral nutrients in a spray solution depend on plant species, plant development stage, nutritional plant status, plant healthiness, and weather conditions.

\section{REFERENCES}

Agina Effat, A.M., H.S.A. Shalaby; A. S. M. El-khayat and H.M.M. Korkar (2005) Effect of foliar fertilization and some growth regulators on growth and chemical composition of some ornamental plants. The $6^{\text {th }}$ Arabian Conference for Horticulture, Ismailia, Egypt.

Anonymous (2009). Brassica nigra. From Wikipedia, the free encyclopedia. http://en.wikipedia.org/wiki/Brassica_nigra

Atta-Alla, H. K. (2003). Effect of different growth media and fertilization on the vegetative growth, flowering and chemical composition of Cineraria Sencio cruntus plants. Alex. J. Agric. Res., 48(2);101-114.

Bentley M. (1982): Commercial Hydroponics. Facts And Figures. $4^{\text {th }}$ edition. Bendon books. Johannesburg. South Africa.

Bowma n D.C. and J .L. Paul (1992). Foliar absorption of urea, ammonium and nitrate by perennial ryegrass turf. J. AMER. SOC. HORT. SCI. 117: 7579.

Brickell,C and J. Zuk (1996) A-Z Encyclopedia of garden plants. DK Publishing USA.

El-Gendy, S. A.; A. M. Hosni; S. S. Ahmed and R. M. Saber (2001). Sweet basil (Ocimum basilicum) productive under different organic fertilization and inter-plant spacing levels in a newly reclaimed land in Egypt. Ann. Agric. Sci., Ain Shams Uni., 46(1): 319-338.

El-Ghawwas, E. O., M. A. Eid and S. M. Mohamed (2202). Effect of different levels of organic manures and plant distances on fennel (Foeniculum vulgar. Miller ) plant. Egypt J. of Applied Science, 17(3); 198-219.

El-Sallami Ismail, H. and Gad, Mohamed M, (2005). Growth and flowering responses of new york Aster ( Aster novi-belgiil.) to a slow release fertilizer and foliar applied Zinc. Assuit Journal of Agricultural Science, 36 (2): 123-136.

El-Sayed, A. A., M. A. Sidky, H. A. Mansoure and M. A. Mohsen (2003). Response of basil (Ocimum basilicum) to different chemical and organic fertilization treatments. J. Agric. Sci, Mansoura Univ. 28(2): 1401-1418.

Frost, M.D., J.C. Cole and J.M. Dole (2003). Fertilizer source affects iron, manganese and Zinc leaching nutrient distribution and geranium growth. J. Plant Nutrition 26 (2): 315-329.

Fritz, A. 1978. FOLIAR FERTILIZATION - A TECHNIQUE FOR IMPROVED CROP PRODUCTION. Acta Hort. (ISHS) 84:43-56 http://www.actahort.org/books/84/84_5.htm

Furuya S ., and Y. Umemiya 2002. The influence of chemical forms on foliar applied nitrogen absorption for peach trees. ACTA HORTIC. 594: 97103. 
Gomez K. A. and R. Gomez (1984) Statistical procedure for agricultural research , $2^{\text {nd }}$ Ed., John Wiley and Sons., Inc. New York, 680, pp.

James A. (2002) The Handbook of Medicinal Herbs $2^{\text {nd }}$ edition. CR, Press. Washington, D. C.

Kannan S. 1980. Mechanisms of foliar uptake of plant nutrients: accomplishments and prospects. J. PLANT NUTR. 2: 717735.

Knoche M., P . D. Petracek Bukovac M. J . , Shafer W .E . 1994. Urea penetration of isolated tomato fruit cuticles. J. AMER. SOC. HORT. SCI. 119: 761764.

Kolattukudy, P.E. (1996) Biosynthetic pathways of cutin and waxes, and their sensitivity to environmental stresses. In: Plant Cuticles. Ed. by G. Kerstiens, BIOS Scientific publishers Ltd., Oxford, pp 83-108

Kolota, E. and M. Osinska (2001). Efficiency of foliar nutrition of field vegetables grown at different nitrogen rates. Acta Hort. 563:87-91. http://www.actahort.org/books/563/563 10.htm

Manoly, N. D. (2001). Effect of soil type and some microelements treatment on growth, flowering and chemical composition of Zennia elegens plants. Proc. $5^{\text {th }}$ Hort-Conf. Ismailia, Egypt, P.193-210.

Marschner H. 1995. Mineral Nutrition of Higher Plants. Academic Press, London, pp 887.

Moghazy, E.I. and Y.M. El-fattah (2005). Effect of cultivar and fertilization sources on the vegetative growth, yield and chemical constituents of reselle plants ( Hibiscus sabdraiffa L.).

Mortvedt, J. J., F. R. Cox, L. M. Shuman and R. M. Welch (1991) Micronutrients in agriculture. $2^{\text {ed }}$ edition. Soil. Sci. Soc. Am. Book Series No. 4 Soil Sci. Soc. Am., Madison, Wisconsin USA.

Omer, E. A. (1992). Effect of Zin and Manganese spraying on the growth, yield, essential oils and pigments of Tagetes patula. Bull. NRC, Egypt, 17(4): 205-212.

Reickenberg R . L . and M .P. Pritts 1996. Dynamics of nutrient uptake from foliar fertilizers in red raspberry. J. AMER. SOC. HORT. SCI. 121: 158163.

Sadasivam, S. and A. Manickam. (1991). Biochemical Methods For Agricultural Sciences. Wiley Eastern limited and Tamil Nadu Agricultural University.

Salem, Amal G. and A. M. Awad (2005) Response of coriander plants to organic and mineral fertilizers in sand soils. Egypt J. Agric. Res., 83 (2): 829-857.

Shaaban, M. M., El-Fouly, M. M., A. El-Zanaty, , and A. W. A. Abdel-Maguid, (2004). Halophytes and foliar fertilization as a useful technique for growing processing tomatoes in the saline affected soils. Pakistan J. of Biol. Sci. Vol. 7 (4): 503-507.

Taiz, L. and E. Zeiger (2008). A Companion to Plant Physiology. $4^{\text {th }}$ Online Edition. (Web site). 
Trejo-Téllez, L.I., Rodríguez-Mendoza, M.N., Alcántar-González, G. and Gómez-Merino, F.C. 2007. EFFECT OF FOLIAR FERTILIZATION ON PLANT GROWTH AND QUALITY OF MEXICAN HUSK TOMATO (PHYSALIS IXOCARPA BROT.). Acta Hort. (ISHS) 729:295-299 http://www.actahort.org/books/729/729_48.htm

Weinbaum S . A . (1988). Foliar nutrition of fruit trees. In: P.M. Neumann (ed.), Plant growth and leafapplied chemicals, CRC Press, Boca Raton Florida, pp. 81100

Weinbaum S .A. , P .H. Brown and R. S. Johnson (2002). Application of selected macronutrients $(\mathrm{N}, \mathrm{K})$ in deciduous orchards: physiological and agrotechnical perspectives. ACTA HORT. 594: 5964.

Wittwer S .H,; M. J . Bukovac; W.H. Jyung, Yamada Y., Rasmussen H.P., Marian S.H. , Kannan S . (1967). Foliar absorption - penetration of the cuticular membrane and nutrient uptake by isolated leaf cells. QUAL. PLANT. 14: 105120.

Wójcik, P. (2004). Uptake of mineral nutrients from foliar fertilization. J. Fruit Ornam. Plant Res. Special ed. vol. 12: 201-218.

Yamada Y. , W . H. Jyung; S. H. Wittwer; M. J. Bukovac (1965). Effects of urea on ion penetration through isolated cuticular membranes and ion uptake by leaf cells. PROC. AMER. SOC. HORT. SCI. 87: 429432.

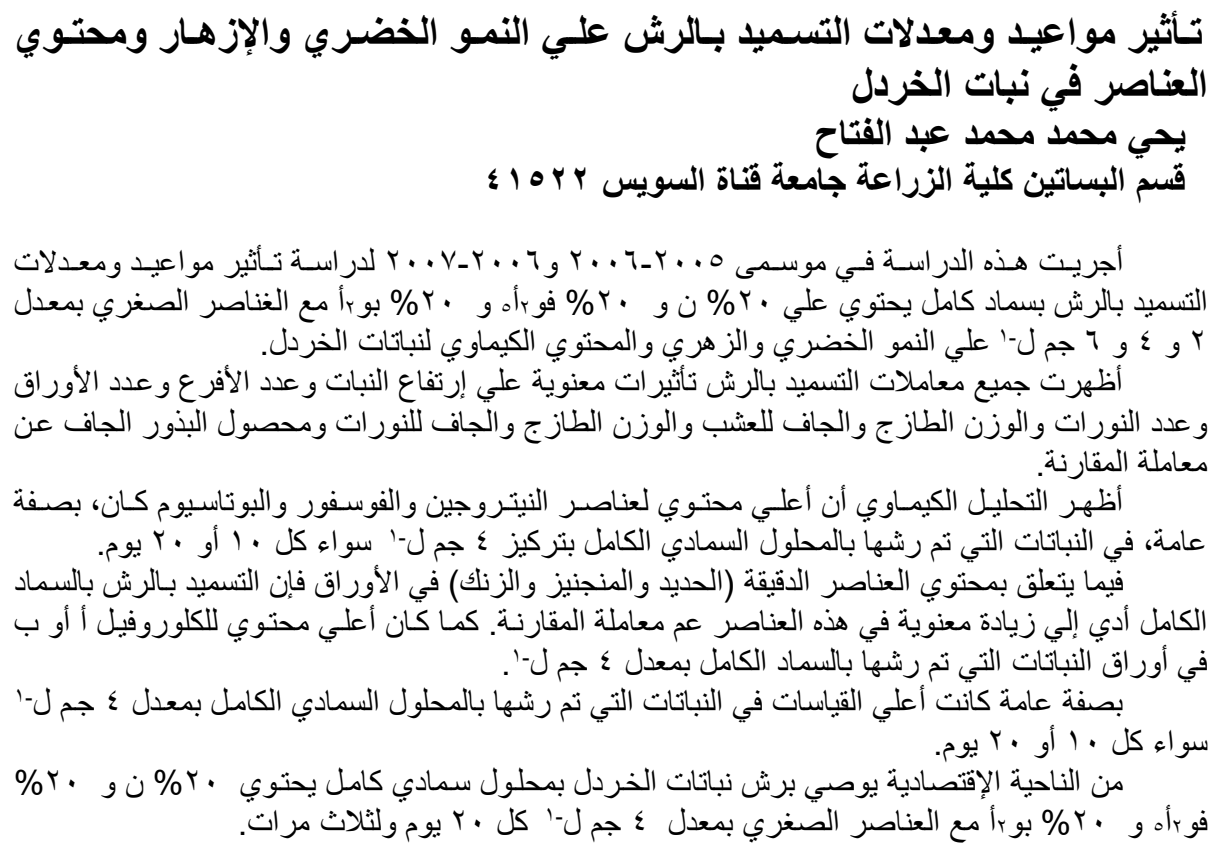

